\title{
DMP1 wt Allele
}

National Cancer Institute

\section{Source}

National Cancer Institute. DMP1 wt Allele. NCI Thesaurus. Code C95576.

Human DMP1 wild-type allele is located in the vicinity of $4 \mathrm{q} 21$ and is approximately $14 \mathrm{~kb}$ in length. This allele, which encodes dentin matrix acidic phosphoprotein 1 , is involved in the modulation of ossification. Mutation of the gene is associated with autosomal recessive hypophosphatemic rickets. 